\title{
Induction of Chitinase, $\beta$-1,3-Glucanase, and Phenylalanine Ammonia Lyase in Peach Fruit by UV-C Treatment
}

\author{
Ahmed El Ghaouth, Charles L. Wilson, and Ann M. Callahan
}

First author: Universite De Nouakchott, Faculte des Sciences et Techniques, Nouakchott, Mauritania, B.P. 5026; and first, second, and third authors: U.S. Department of Agriculture-Agricultural Research Service, Appalachian Fruit Research Station, 45 Wiltshire Road, Kearneysville, WV 25430.

Accepted for publication 1 October 2002.

\section{ABSTRACT}

El Ghaouth, A., Wilson, C. L., and Callahan, A. M. 2003. Induction of chitinase, $\beta$-1,3-glucanase, and phenylalanine ammonia lyase in peach fruit by UV-C treatment. Phytopathology 93:349-355.

Treatment of peach fruit with UV-C light caused a rapid induction of chitinase, $\beta$-1,3-glucanase, and phenylalanine ammonia lyase (PAL) activities starting $6 \mathrm{~h}$ after treatment and reaching maximum levels at $96 \mathrm{~h}$ after treatment. By $96 \mathrm{~h}$ after UV-C treatment, chitinase, $\beta$-1,3-glucanase, and PAL activities in UV-C-treated fruit were over twofold above the levels observed for the control. In nontreated control fruit, no apparent increase in chitinase and $\beta$-1,3-glucanase activities was detected but a minor increase in PAL activity was seen. The transient increase in chiti-

Strengthening the endogenous defense capabilities of plants has been advanced as a promising strategy for crop protection. Several active microbial and chemical elicitors have been identified and shown to induce systemic resistance in a variety of plants $(11,16$, $17,21)$. In recent years, there have been several attempts to manipulate inducible defense mechanisms of harvested commodities through prestorage treatments with innocuous abiotic and biotic elicitors to control postharvest decay. The reduction of postharvest decay of several harvested commodities by prestorage treatment with chitosan (10) and UV-C light $(6,19,20,24)$ indicates that induction of defense responses in harvested crops is feasible and manageable on a variety of commodities. Among the elicitors, nonionizing UV-C (from 190 to $280 \mathrm{~nm}$ ) radiation has been the most extensively studied and substantial progress has been made in this area $(6,20,24)$.

Prestorage treatment of a variety of commodities including pome, stone, and citrus fruit with low dose of UV-C has been shown to reduce decay. This response has been attributed to the induction of antifungal secondary metabolites by UV-C rather than to its germicidal effect $(6,19,20,24)$. In lemon fruit and carrots, UV-C treatment triggered a gradual development of tissue resistance that coincided with the accumulation of the phytoalexin scoparone and 6-methoxymellen $(19,20)$. In grapefruit, the onset of resistance to infection by Penicillium digitatum was shown to coincide with the accumulation of an isoflavone reductase-like protein transcript (18) and with the induction of phenylalanine ammonia lyase (PAL) activity (6). Similarly, in peach fruit the induction of disease resistance by UV-C treatment was also

Corresponding author: C. L. Wilson; E-mail address: cwilson@afrs.ars.usda.gov

Publication no. P-2003-0120-03R

This article is in the public domain and not copyrightable. It may be freely reprinted with customary crediting of the source. The American Phytopathological Society, 2003. nase, $\beta$-1,3-glucanase, and PAL activities in UV-C-treated fruit was preceded by a gradual activation of the corresponding genes. UV-C-treated fruit showed an increase in accumulation of $\beta$-1,3-glucanase and chitinase mRNAs at $3 \mathrm{~h}$ after treatment, which peaked approximately $96 \mathrm{~h}$ posttreatment. A similar induction kinetic pattern was observed for PAL mRNA in response to UV-C treatment, except the induction started $6 \mathrm{~h}$ after UV-C treatment. These results show that the response of peach fruit to elicitor treatment is similar to that seen in other plant-elicitors interactions and suggests the involvement of peach biochemical defense responses in UV-C-mediated disease resistance.

Additional keywords: antagonistic yeast, apple, Botrytis cinerea, gray mold. attributed to the induction of PAL activity and the delay of ripening (24).

Although a putative role of other defense responses apart from phytoalexin accumulation in UV-C-mediated resistance has often been inferred, it has not been substantiated. In several plant systems, the induction of systemic resistance against a broad spectrum of microbial pathogens is often correlated with the expression of at least nine gene families including class III chitinase and $\beta$-1,3-glucanase $(17,21,25)$. A limited amount of basic information has been published regarding the involvement of antifungal glucanohydrolases in UV-C-induced resistance in harvested commodities. Such information would allow the development of a more effective strategy aimed at exploiting the potential of UV-C treatments. In this paper, we describe the differential accumulation kinetics of chitinase, $\beta$-1,3-glucanase, and PAL in UV-C-treated peach fruit. In addition, we report the isolation and identification of a peach chitinase and a PAL gene.

\section{MATERIALS AND METHODS}

Reagents and fruit. Peach fruit (Prunus persica L. Batsch cv. Loring) were hand-harvested at the firm ripe stage (5.5 to $8.5 \mathrm{~kg}$ of pressure) at the Appalachian Fruit Research Station, Kearneysville, WV. Fruit were sorted on the basis of size and absence of physical injuries or infections and stored at $0^{\circ} \mathrm{C}$ for $24 \mathrm{~h}$ prior to their use.

UV irradiation. Two low-pressure, mercury-vapor, discharge lamps (General Electric, Fairfield, CT) emitting quasi-monochromatic UV radiation at $254 \mathrm{~nm}$ were used. The lamps were mounted $2.5 \mathrm{~cm}$ apart on a cast-iron frame with stainless steel reflector, and the UV-C lamp suspension frame was placed inside a thin box enclosure ( $32 \mathrm{~cm}$ wide and $64 \mathrm{~cm}$ long). Fruit were placed on a tray approximately $10 \mathrm{~cm}$ from the surface of the lamp and exposed to a UV-C dose of $7.6 \mathrm{~kJ} / \mathrm{m}^{2}$, measured by a UVX radiometer (UVP, Inc., San Gabriel, CA) for $10 \mathrm{~min}$. Fruit were individually rotated to ensure that all sides of the fruit were exposed to 
UV-C. UV-treated fruit and their controls were stored at $24^{\circ} \mathrm{C}$ under high $(95 \%)$ relative humidity in plastic containers. Treatments consisted of four replicates of 16 fruits each and were arranged in a complete randomized block design. The experiment was maintained for 1 week and conducted twice. Tissue samples were collected at various times $(0,3,6,12,24,48$, and $96 \mathrm{~h})$ after treatment from eight fruit randomly selected from each treatment, two fruit per replicate. From each fruit, the outer tissue $(2 \mathrm{~mm})$ was collected, frozen in liquid nitrogen, lyophilized, and stored at $-20^{\circ} \mathrm{C}$.

Enzyme preparation and assay. Tissue samples were individually extracted in a prechilled mortar and pestle in 2 volumes

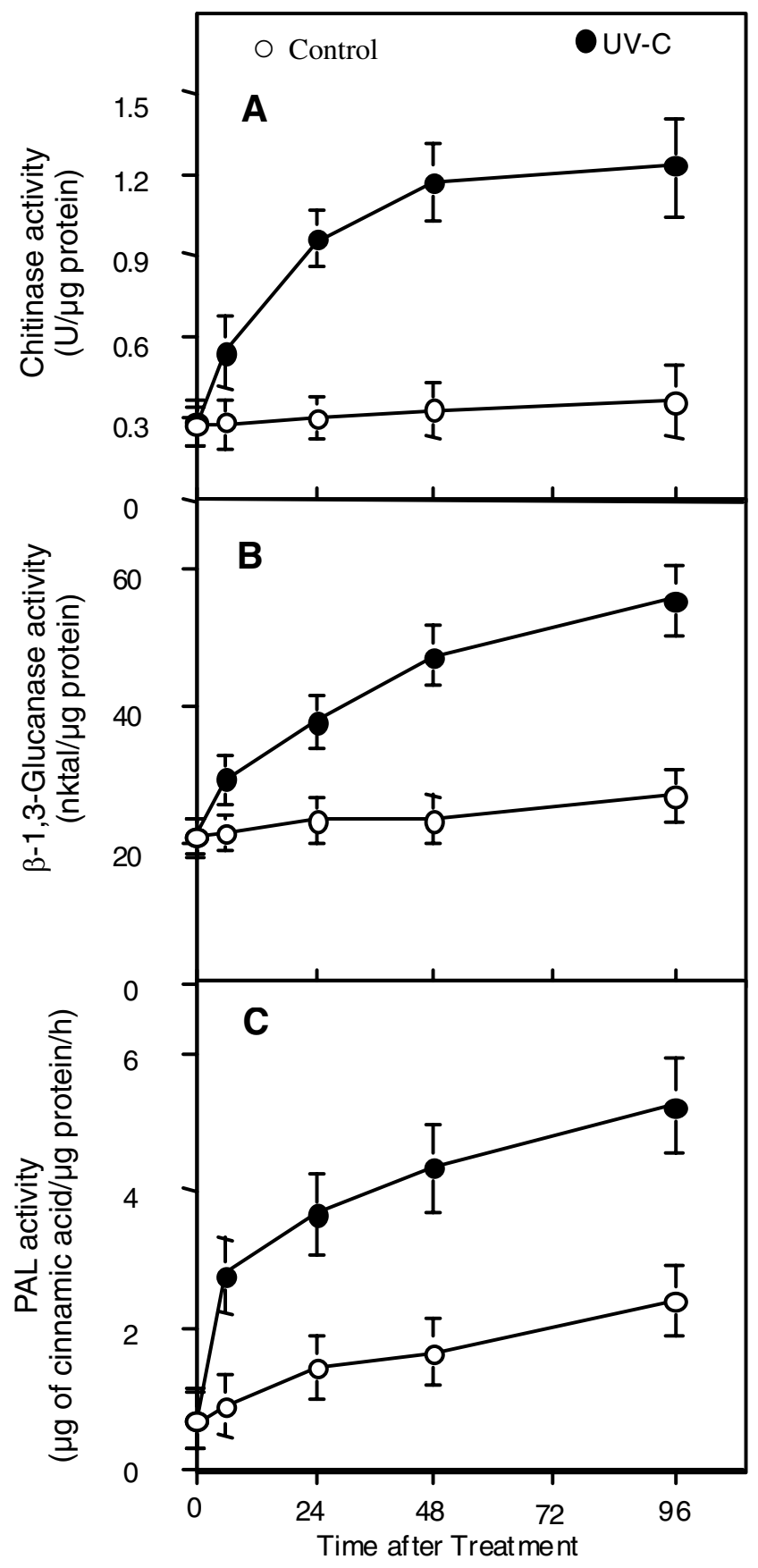

Fig. 1. Time course of changes in $\mathbf{A}$, chitinase, $\mathbf{B}, \beta-1,3$-glucanase, and $\mathbf{C}$, phenylalanine ammonia lyase (PAL) activities in extracts of peach fruit treated with UV-C $(\bullet)$ or sterile water $(0)$. Extracts were obtained 0, 6, 24, 48, and $96 \mathrm{~h}$ after treatment, and enzyme activities were determined as described in in the text. The figure is based on the data from one of two experiments conducted. Bars represent standard deviations. (wt/vol) of $50 \mathrm{mM}$ sodium acetate buffer, $\mathrm{pH}$ 5.0. The homogenate was centrifuged at $4^{\circ} \mathrm{C}(10,000 \times g$ for $15 \mathrm{~min})$, and the supernatant was dialyzed at $4{ }^{\circ} \mathrm{C}$ against two changes of water and two changes of $10 \mathrm{mM}$ sodium acetate ( $\mathrm{pH}$ 5.0) overnight. Samples were then lyophilized and reconstituted in sterile distilled water. Protein concentrations were determined with a protein assay kit (Bio-Rad Laboratories, Hercules, CA).

Chitinase activity was assayed with a dye-labeled carboxymethylchitin according to the method described by Wirth and Wolf (27). Chitinase activity was measured by mixing $100 \mu \mathrm{l}$ of crude enzyme solution with $200 \mu$ of $2 \%$ dye-labeled carboxymethylchitin in $50 \mathrm{mM}$ sodium acetate buffer ( $\mathrm{pH} 5.0)$. After $2 \mathrm{~h}$ of incubation at $37^{\circ} \mathrm{C}$, the reaction was stopped by adding $100 \mu \mathrm{l}$ of $1.0 \mathrm{M} \mathrm{HCl}$, the reaction mixture was cooled and centrifuged, and the absorbance of the supernatant was measured at $550 \mathrm{~nm}$. Chitinase activity was calculated according to Wirth and Wolf (27) and was measured in international units (U) per microgram of total protein. One unit was defined as the amount of enzyme required to catalyze the formation of $1 \mathrm{nmol}$ product per minute.

$\beta-1,3$-Glucanase activity was determined following the method of Abeles and Forrence (1) by incubating $62.5 \mu \mathrm{l}$ of enzyme preparation for $24 \mathrm{~h}$ at $40^{\circ} \mathrm{C}$ in $62.5 \mu \mathrm{l}$ of $4 \%$ laminarin. The reaction was terminated by heating the sample in boiling water for $5 \mathrm{~min}$ and the amount of reducing sugars was measured spectrophotometrically at $492 \mathrm{~nm}$ after reaction with $372 \mu \mathrm{l}$ of 3,5-dinitrosalicyclic reagent. Final activity values are reported as nanokatal (nktal) per microgram of total protein. One nanokatal was defined as the enzyme activity catalyzing the formation of $1 \mathrm{nmol}$ glucose equivalents per second.

PAL activity was determined following the method of BeaudoinEagan and Thorpe (3). The reaction mixture for PAL activity consisted of $6 \mu \mathrm{M}$ L-Phe in $0.5 \mathrm{M}$ Tris- $\mathrm{HCl}$ buffer $(\mathrm{pH} 8.0)$ and $200 \mu \mathrm{l}$ of enzyme preparation. After 1 to $2 \mathrm{~h}$ of incubation at $37^{\circ} \mathrm{C}$, the reaction was stopped by adding $500 \mu \mathrm{l}$ of $5.0 \mathrm{M} \mathrm{HCl}$. The reaction mixture was cooled and centrifuged and the amount of cinnamic acid produced was measured spectrophotometrically at $290 \mathrm{~nm}$. PAL activity was expressed as micrograms of cinnamic acid per microgram of protein.

Cloning. The predicted amino acid sequences for PAL and basic chitinase were aligned using the multiple sequence alignment program of PCGENE (Mountain View, CA) from Phaseolus vulgaris, Pisim sativum, and Populus trichocarpa $\times$ Populus deltoides for PAL (GenBank Accession Nos. M11939, D10002, and L11747, respectively) and Solanum tuberosum, Pisim sativum, and Populus trichocarpa $\times$ Populus deltoides for chitinase (GenBank Accession Nos. X07130, X63899, and M25336, respectively). Polymerase chain reaction (PCR) degenerate primers were designed to amplify a region of PAL from amino acids GQIEAAA (GGTCAAATTGAGGCTGC[T/T/A]GC) at the $5^{\prime}$ end to FVREELG (CCCAACTC[T/C/C $]$ T[C/C/G][T/T/C $]$ CTCACAAAC) at the $3^{\prime}$ end, resulting in a predicted fragment of 1,068 bases not including introns. Primers were designed to amplify basic chitinase from amino acids QTSHETT (CA[G/A/A]AC[A/T/T]TC[T/C]CATGAAACTAC) at the 5' end to DRIGFY (GATCG[C/C/G][A/A/G]TT$\mathrm{GG}[\mathrm{A} / \mathrm{A} / \mathrm{G}] \mathrm{TT}[\mathrm{T} / \mathrm{T} / \mathrm{C}] \mathrm{TAC})$ at the $3^{\prime}$ end. This would result in the amplification of approximately 474 bases not including introns.

The primers were used to amplify DNA from a lambda peach genomic library (A. M. Callahan, personal communication) (2) and peach DNA ('Suncrest') using AmpliTaq Gold (Perkin-Elmer Applied Biosystems, Norwalk, CT). The PCR product was precipitated and eluted over an elutip D column (Schleicher \& Schuell, Keene, NH) following manufacturer's recommendations, reamplified with the same primers, and cloned into pCRII vector (Invitrogen, Carlsbad, CA) following manufacturer's directions. Clones were sequenced by the BigDye terminator kit from PEApplied Biosystems.

Hybridization probes. Template DNAs were amplified through PCR with either specific primers or flanking vector primers under 
standard conditions as recommended by the manufacturer (PEApplied Biosystems). The reactions were precipitated and eluted through an elutip column $(\mathrm{S}+\mathrm{S})$. An Arabidopsis $\beta$-1,3-glucanase cDNA (BG-2), supplied by F. Ausubel was used as probe for $\beta$ 1,3-glucanase. PCR-amplified inserts for PAL, chitinase, and $\beta$ 1,3-glucanase were precipitated twice, first in the elution $\mathrm{NaCl}$ and then with a final concentration of $2 \mathrm{M}$ ammonium acetate. The inserts were quantitated on the gel and anywhere from 50 to $100 \mathrm{ng}$ of DNA were random-primer labeled with $\left[\alpha-{ }^{32} \mathrm{P}\right]-\mathrm{dCTP}$ according to the manufacturer (Life Technologies, Inc., Rockville, MD). The labeled DNA was separated from unincorporated counts by a G-50 packed 'spin' column and the probes were denatured by boiling for $3 \mathrm{~min}$ and added to the prehybridization mixture.

DNA and RNA extraction. Genomic DNA was isolated as described by Doyle and Doyle (8) using 3\% (wt/vol) mixed alkyltrimethyl-ammonium bromide and $1 \%$ (wt/vol) polyvinylpyrrolidone-40 in the extraction buffer. Purified DNA was evaluated by UV light for integrity and amount after resolution on $0.7 \%$ agarose gel and ethidium bromide staining.

Total RNA was extracted following the method of Callahan et al. (5) with minor modification. Peach tissue was extracted with preheated $65^{\circ} \mathrm{C}$ proteinase $\mathrm{K}$ buffer containing ascorbic acid $(1 \mathrm{mM}$ final concentration). The supernatant was extracted twice with heated phenol $\left(65^{\circ} \mathrm{C}\right)$ and then with room temperature phenol. The protocol was continued as before (5) using phenol-chloroform extraction, chloroform extraction, $\mathrm{LiCl}$ precipitation, and ethanol precipitation. The integrity of the RNA was visualized following electrophoresis through a $1.4 \%$ agarose gel and ethidium bromide staining.

Northern blot analyses. RNA samples, $10 \mu \mathrm{g}$ per lane, were denatured, fractionated on $1.4 \%$ agarose gels containing $2.2 \%$ (vol/vol) formaldehyde, and transferred to Nytran (Schleicher \& Schuell) nylon membrane according to the manufacturer's instructions for capillary transfer. The membranes were stained with methylene blue (14) to verify equal amounts of RNA in each lane following the transfer. RNA was covalently attached to the membranes by UV-crosslinking $\left(0.3 \mathrm{~J} / \mathrm{cm}^{2}\right.$; Bioslink, New Haven, CT).

Filters were prehybridized for $3 \mathrm{~h}$ and hybridized overnight at $42^{\circ} \mathrm{C}$ in Hybrisol $(50 \%$ [ $\mathrm{vol} / \mathrm{vol}$ ] formamide, $6 \times \mathrm{SSC}$ [ $1 \times \mathrm{SSC}$ is $0.15 \mathrm{M} \mathrm{NaCl}$ plus $0.015 \mathrm{M}$ sodium citrate], and $10 \%$ [wt/vol] dextran sulfate) (Oncor, Gaithersburg, MD). Filters were then washed at $25^{\circ} \mathrm{C}$ for $1 \mathrm{~h}$ with two changes of $0.1 \times \mathrm{SSC}$ followed by two $1 / 2$-h washes at $65^{\circ} \mathrm{C}$ with $0.1 \times \mathrm{SSC}$. Autoradiography was performed at $-80^{\circ} \mathrm{C}$ on Kodak XAR-5 film (Kodak, Rochester, NY). Membranes were prehybridized again and hybridized with a ribosomal $18 \mathrm{~S}$ probe (9) to verify evenness in loading.

Southern blot hybridization. Genomic DNA samples $(6 \mu \mathrm{g})$ were digested with EcoRI, HindIII, or BamHI. The resulting restriction fragments were fractionated on $0.7 \%$ agarose gels and blotted by capillary transfer to nitrocellulose membranes. The membranes were baked at $65^{\circ} \mathrm{C}$ under a vacuum for $2 \mathrm{~h}$. Hybridization and wash conditions were as described previously for RNA blots.

\section{RESULTS}

Induction of antifungal hydrolases. The analyses of the induction kinetics of chitinase, $\beta$-1,3-glucanase, and PAL in UV-Ctreated peach are shown in Figure $1 \mathrm{~A}$ to $\mathrm{C}$. UV-C treatment markedly increased chitinase, $\beta$-1,3-glucanase, and PAL activities by $6 \mathrm{~h}$ after treatment, reaching maximum levels within $96 \mathrm{~h}$ after treatment (Fig. 1A to C). At $96 \mathrm{~h}$ after treatment, chitinase and $\beta$ 1,3-glucanase activities increased by more than threefold and twofold, respectively, compared with control levels (Fig. 1A and B). In nontreated control fruit, chitinase and $\beta$-1,3-glucanase activities were low and did not change drastically with time (Fig. 1A and B). Analysis of the induction of PAL activity also showed a similar pattern as seen for chitinase and $\beta$-1,3-glucanase in UV-Ctreated peaches. PAL activity increased in UV-C-treated tissue with time, reaching its maximum in $96 \mathrm{~h}$ after treatment (Fig. 1C). At $96 \mathrm{~h}$ after treatment, PAL activity was induced over twofold above that observed in control fruit. Only a slight increase in PAL activity was detected in nontreated tissue.

Induction of chitinase, glucanase, and PAL mRNA. Difficulties in using heterologous probes necessitated the isolation of peach-specific probes for both chitinase and PAL. A chitinase partial genomic sequence was isolated through PCR using 'Suncrest' peach genomic DNA as template and degenerate primers to basic chitinase (GenBank Accession No. AF206635). The chitinase clone contained 903 bases starting from the translated QTSHETT and ending at DRIGFY. There were two introns, one of 246 bases and one of 180 bases. The predicted amino acid sequence is most related to that of cicer at $82 \%$ as well as cacao,

\begin{abstract}
pch QTSHETTGGWASA-PDGPYSWGYCYLKEQ-NPG-SYCAWD PNYPCAAGKQYYGRGPIQLSWNYNYGQCGKAIGEDLLNNP cicer QTSHETTGGWSSA-PDGPYAWGYCFLREQ-NPS-TYCQPS SEYPCASGKQYYGRGPIQLSWNYNYGQCGRAIGVDLLNNP avo QTSHETTGGWATA-PDGPYAWGYCFLKEQGNPP-DYCVPT AQWPCAPGKKYYGRGPIQISYNYNYGPAGRAIGYDLINNP cacao QTSHETTGGAGWAAPDGPYTWGYCYNREL-NPA-DYCQWD PNYPCAPGKQYFGRGPMQLT-NYNYGQCGRAIGVDLLNNP vit QTSHETTGGWASA-PDGPYAWGYCYLREQGSPG-AYCVPS AQWPCAAGRKYYGRGPIQISYNYNYGQAGKAIGVDLVNNP pot QTSHETTGGWASA-PDGPYAWGYCFLRERGNPG-DYCPPS SQWPCAPGRKYFGRGPIQISHNYNYGPCGRAIGVDLLNNNP tob QTSHETTGGWATA-PDGPYAWGYCWLREQGSPG-DYCTPS GQWPCAPGRKYFGRGPIQISHNYNYGPCGRAIGVDLLNNP bean QTSHETTGGWATA-PDGPYAWGYCFVRER-NPS-AYCSAT PQFICAPGQQYYGRGPIQISWNYNYGQCGRAIGVDLLNKP arab QTSHETT-GWATA-PDGPYSWGYCFKQEQ-NPASDYCEPS ATWPCASGKRYYGRGPMQLSWNYNYGLCGRAIGVDLLNNP
\end{abstract}

120

pch DLVATDPVISFKTALWFWMTPQSPKPSCHDVITGRWNPSG ADKSAGRVPGYGVTTNIINGGLECGKGWNAKVEDRVGFY cicer DLVATDPVISFKTAIWFWMTPQSPKPSCHDVITGRWNPST SDRAAGRLPGYGTVTNI INGGLECGRGHDSRVQDRIGFY avo DAVATDPVISFKTALWFWMTPQSPKPSCHNVITGRWTPSA ADRAAGRLPGYGVITNIINGGIECGKGFNDKVADRIGFY cacao DLLATDPTISFKSAFWFWMTPQSPKPSCHDVIIGAWSPSG SDQAAGRVPGFGLITNI INGGLECGQGWNAKVEDRIGFY vit DLVATDAVISFKTAFWFWMTPQSPKPSCHNVITGGWTPSG ADRSAGRLPGFGVITNIINGGVECGKGVVPQVQDRIGFY pot DLVATDPVISFKTALWFWMTPQSPKPSCHDVIIGRWNPSS ADRAANRLPGFGVITNI INGGLECGRGTDNRVQDRIGFY tob DLVATDPVISFKSALWFWMTPQSPKPSCHDVIIGRWQPSS ADRAANRLPGFGVITNIINGGLECGRGTDSRVQDRIGFY bean DLVATDSVISFKSALWFWMTAQSPKPSSHDVITSRWTPSS ADVAARRLPGYGTVTNI INGGLECGRGQDSRVQDRIGFF arab DLVANDAVIAFKAAIWFWMTAQPPKPSCHAVIAGQWQPSD ADRAAGRLPGYGVITNIINGGLECGRGQDGRVADRIGFY

Fig. 2. Amino acid comparison of peach and other plant putative chitinase class I sequences derived from DNA sequences. pch $=$ peach sequence from this work (GenBank Accession No. AF206635), cicer $($ AJ012821), avo = avocado $(Z 78202)$, cacao $($ U30324), vit = grape $($ P51613), pot = potato $($ P05315), tob = tobacco (M15173), bean (P36361), and arab = Arabidopsis (M38240). The probe sequence for peach chitinase was generated using primers to the underlined amino acids and consisted of the whole sequence presented here as well as two intervening intron sequences. 
grape, and avocado at 79 to $80 \%$ (Fig. 2). It ranged in identity to Arabidopsis at $75 \%$ and to potato at $79 \%$. The peach sequence represents a basic chitinase type I gene.

A peach PAL sequence was generated through PCR using a 'Suncrest' genomic library in the vector Lambda Dash and degenerate primers to PAL. Ten resulting clones were sequenced and of these four contained the expected PAL sequences (GenBank Accession No. AF206634). No introns were found in the 1,068 bases of the peach PAL sequenced. As expected, it has closest sequence identity with woody perennials (Fig. 3). The highest homology at the predicted amino acid level is $87 \%$ with camellia, carrot, lemon, aspen, grape, poplar, and sweet cherry.

Hybridization of peach genomic DNA with PCR-amplified inserts for peach chitinase detected a small family of genes as indicated in Figure 4A with a few closely related genes as suggested by the two major fragments in Figure 4B. The low stringency wash for PAL indicates a smaller family (Fig. 4C) than chitinase with a single related gene for PAL under stringent wash conditions (Fig. 4D). The two fragments detected in the HindIII digest are expected because of an internal HindIII site.

RNA induction. To determine whether the induction of chitinase, $\beta$-1,3-glucanase, and PAL activity was due to gene activa- tion and de-novo synthesis of these enzymes, total RNA isolated from treated and untreated tissue was analyzed. The peach chitinase sequence detected a transcript of $1.2 \mathrm{~kb}$ that was barely detectable in untreated fruit but increased in the UV-C-treated fruit (Fig. 5A and B). At $6 \mathrm{~h}$ after treatment, UV-C-treated tissue showed a higher level of chitinase transcript than the control and attained the maximum level at approximately $96 \mathrm{~h}$ posttreatment. Hybridization of a heterologous cDNA probe encoding for Arabidopsis $\beta$-1,3-glucanase (BG-2) with the fruit RNAs resulted in an appreciable constitutive amount of a $1.4-\mathrm{kb}$ putative $\beta$-1,3-glucanase mRNA in control tissue that increased slightly by $96 \mathrm{~h}$ after treatment (Fig. 6A). The kinetics of the accumulation of putative $\beta$-1,3-glucanase mRNA in response to the UV-C treatment followed the same pattern as seen for chitinase. In UV-C-treated fruit, putative $\beta$-1,3-glucanase mRNA increased from basal level at $3 \mathrm{~h}$ after treatment with the maximum accumulation occurring after $96 \mathrm{~h}$ (Fig. 6B). Using the peach PAL sequence as a probe, a small increase in PAL transcript occurred after $24 \mathrm{~h}$ of storage that peaked at $96 \mathrm{~h}$ in the control fruit, but the level of increase was much lower than that seen in UV-C-treated fruit (Fig. 7A and B) where the increase was detected by $6 \mathrm{~h}$ and peaked also at $96 \mathrm{~h}$.

pch QIEAAAIMEHILAGSDYVKAAEKVHDLDPLQK-PKQDRYA-LRTS cher QIEAAAIMEHILDGSSYVKAAKKLHEQDPLQK-PKQDRYA-LRTS grap QIEAAAIMEHILDGSSYVKEAKKLHEMDPLQK-PKQDRYA-LRTS arab QIEAAAIMEHILDGSSYMKLAQKVHEMDPLQK-PKQDRYA-LRTS popl QIEAAAVMEHIIDGSSYVKAAQKLHEIDPLQK-PKQDRYA-LRTS spot QIEAAAIMEHILDGSSYVKAAQKLHEMDPLQK-PKQDRYA-LRTS avo QIEAAAIMEHILDGSSYMKVAKKLHELDPLQK-PKQDPYAALRTS bean QIEAAAIMEHILDGSSYMKDAKKLHEIDPLQK-PKQDRYA-LRTS cant QIEAAAIMEHLLDGSASQKDAKRLHELDPLQNSPKQDRYA-LRTS

pch GTPIGVAMDNT-RLAIAAIGKLMFAQFSELVNDFYNNGLPSNLTG cher GTPIGVSMDNT-RLAIASIGKLMFAQFSELVNDFYNNGLPSNLSG grap GTPIGVSMDNT-RLAIAAIGKLMFAQFSELVNDFYNNGLPSNLSG arab GTPIGVSMDNT-RLAIAAIGKLMFAQFSELVNDFYNNGLPSNLTA popl GSPIGVSMDNTLVLAIASIGKLMFAQFSELVNDYYNNGLPSNLTG spot GTPIGVSMDNS-RLALASIGKLLFAQFSELVNDYYNNGLPSNLTA avo GTPIGVSMDNT-RLAIAAIGKLMFAQFSELVNDFYNNGLPSNLSG bean GTPIGVSMDNT-RLALASIGKLMFAQFSELVNDFYNNGLPSNLTA cant GTPIGVSMDNT-RLALASIGKLLFAQFSELVNDFYNNGLPSNLSG appl

PQWLSPQIEVIRAATKMIEREINSVNDNPLIDVSRNKALHGGNFQ PQWLGPQIEVIRYSTKSIEREIDSVNDNPIIDVSRNKALHGGNFQ PQWLGPHIEVIRASTKSIEREINSVNDNPLIDVSRNKALHGGNFQ PQWLGPQIEVIRQATKSIEREINSVNDNPLIDVSRNKAIHGGNFQ PQWLGPLIEVIRTSTKMIEREINSVNDNPLIDVSRNKALHGGNFP PQWLGPQIEVIRAATKMIEREINSVNDNPLIDVARSKALHGGNFQ PQWLGPQIEVIRNATLSIEREINSVNDNPL IDVSRNKALHGRNFQ PQWLGPLIEVIRFSTKSIEREINSVNDNPLIDVSRNKALHGGNFQ PQWLGPQIEVIRHSTKSIEREINSVNDNPLIDVSRNKALHGGNFQ

SSNPSTDYGFKGA 180 GRNPSLDYGFKGAEIAMASYCSELQFLANPVTNHVQSAEQHNQDV SRNPSLDYGFKGAEIAMASYCSELQFLANPVTNHVESAEQHNQDV SSNPSLDYGFKGAEIAMASYCSELQYLANPVTSHVQSAEQHNQDV GRNPSLDYGFKGAEIAMASYCSELQFLANPVTNHVQSAEQHNQDV GRNPSLDYGFKGAEIAMASYCSELQFLANPVTNHVQSAEQHNQDV GRNPSLDYGFKGAEIAMAAYCSELQFLANPVTNHVQSAEQINQDV SRNPSLDYGFKGAEIAMASYCSELQYLANPVTSHVQSAEQHNQDV GSNPSLDYGFKGAEIAMASYCSELQYLANPVTNHVQSAEQHNQDV QHNQDV

pch NSLGLISSRKTAEAVDVLKLMSSTYLVALCQAVDLRHLEENLKST cher NSLGLISSRKTAEAVDILKLMSSTFLVALCQAIDLRHLEENLRNT grap NSLGLISSRKTAEAVDILKIMSTTYLVALCQAIDLRHLEENLKST arab NSLGLISSRKTSEAVDILKLMSTTFLVGICQAVDLRHLEENLRQT pop1 NSLGLISARKTAEAVEILNVMSTTWLVALCQAIDLRHIEENLKNT spot NSLGLISARKTAEAVDVLKLMSSTYLVALCQAIDLRFLEENLRNA aVo NSLGLISSRKTAEAVEILKLMSSTFLVGLCQAIDLRHLEENLKST bean NSLDLISARKTNESIEILKLMSSTFLMGLCQAIDLRHLEENLKSS cant NSLGLISSRKTAEAIDILKLMSTTFLAALCQAIDLRHIEENLKST app1 NSLGLISSRKTAEAVDILKLMSSTFLVALCQSIDLRHLEENLRNT

315

VKSTVSQVAKRVLTVGFNGELHPSRFCEKDLLKVVDREYVFAYID VKNTVSQVAKRTLTTGVNGELHPSRFCEKDLLKVVDREYVFAYID VKKTVSHVAKKTLTIGANGELHPSRFCEKDLLKVVDREHVFAYID VKNTVSQVAKKVLTTGINGELHPSRFCEKDLLKVVDREQVFTYVD VKNTVSQVAKRVLTMGFNGELHPSRFCEKDLLKVVDREYVFTYID VKNAVTQVAKRTLTVGANGELHPARFCEKDLLRVVDREYVFAYAD VKNTVSQVAKRVLTIGVNGELHPSRFCEKDLIKVVDGEHLFAYID VKNTVSQVSKRTLTTGGNGELHPSRFCEKDLLKVVDREYVFSYID VKNTVSQVAKKILTIGVNGELHLSRFCEKDIILVIDREYCFAYID VKNTVSQVAKRTLTTGVNGELHPSRFCEKDLLKVVDREYVFAYID

\begin{tabular}{|c|c|c|}
\hline & & \\
\hline & 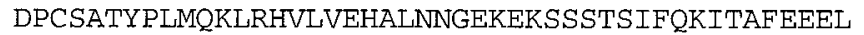 & KTLLPKEVESARLEYDNGKSATPNRIKDCRSYPLYKFVREI \\
\hline cher & DPCSATYPLMQKLRQVLVEHALTNGENEKNASTSIFQ̈KIVAFEEEL & KVLLPKEVDSARAALDSGSAGVPNRITECRSYPLYKF $\overline{\text { VREEL }}$ \\
\hline & DPCSATYPLMQ̄KVRQ̃VLVEHALNNGESEKNGSTSIFQ̈KIGAFEEEL & KAVLPKEVESARDGVESGNPSIPNRIKECRSYPLYKFVREEL \\
\hline $\mathrm{ab}$ & DPCSATYPLMQRLRQVIVDHALSNGETEKNAVTSIFQKIGAFEEEL & KAVLPKEVEAARAAYGNGTAPI PNRIKECRSYPLYRFVREEL \\
\hline opl & DPCSATYPLMQKLRQVLVDHALMNGEKEQNSSTSIFQKIGAFEEEL & KILLPKEVESARLELENGNPAI PNRITDRRSYPLYKFVREEL \\
\hline spot & DPCSANYPLMQKLRQALVDHALQNGENEKNTGTSIFLKVAAFEDEL & KAVLPKEVEAARIAVESGNPAIPNRIKECRSYPLYKFVREGL \\
\hline avo & DPCSCTYPLMQKLRQVLVEHALINGEKEKDSSTSIFQKIGAFEEEL & KTHLPKEVESARIELERGNSAIPNRIKECRSYPLYKFVREEL \\
\hline ean & DPYSGTYPLMQKLRQVLVDHALINAENEKDVNTSIFQKIATFEEEL & KTILPKEVESTRAAYESGKAAIPNKIKECRSYPLYKFVREEL \\
\hline & DPCSMTYPLMOKLRQVLVEHALKNNDDLKNLNSSIFLKIGAFEEEL & KTLLPKEVESGRQAISKGKAI IPIRIKDCRSYPIYKFVREEL \\
\hline & & \\
\hline
\end{tabular}

Fig. 3. Amino acid comparison of peach and other plant putative phenylalanine ammonia lyase $(\mathrm{PAL})$ sequences derived from the DNA sequences. pch $=$ peach sequence from this work (GenBank Accession No. AF206634), cher = cherry (AF036948), grap = grape (X75967), appl = apple $(X 68126)$, arab = Arabidopsis $(\mathrm{L} 33678), \mathrm{popl}=$ poplar $(\mathrm{D} 43803)$, spot $=$ sweet potato $(\mathrm{M} 29232)$, avo $=$ avocado $(\mathrm{U} 16130)$, bean $(\mathrm{S} 46988)$, and cant $=$ cantalope $(\mathrm{X} 76130)$. The probe sequence for peach PAL was generated using primers to the underlined amino acids and consisted of the whole sequence presented here. 


\section{DISCUSSION}

UV-C light treatment induces resistance to infection in several crops including some harvested commodities, and the onset of the resistance has often been correlated with the accumulation of phytoalexins $(4,6,7,13,19,20)$. In this report, we have characterized a peach fruit chitinase and PAL gene with a high homology to chitinase and PAL from tree, dicotyledonous, and monocotyledons. In addition, we have demonstrated that both genes were induced by UV-C treatment. The deduced protein sequences of the peach chitinase showed that the peach chitinase contained an amino acid sequence similar to the main structure of class I chitinase, basic chitinase isoforms that have a cysteine-rich domain at the amino terminus. The DNA restriction patterns suggest that the peach chitinase and PAL are encoded by small gene families, which is reminiscent of the class I chitinase and PAL in other crops $(12,16,25)$.

The analysis of the accumulation kinetics of chitinase, $\beta-1,3-$ glucanase, and PAL in UV-C-treated peaches showed that UV-C radiation caused an accumulation of chitinase, $\beta-1,3$-glucanase, and PAL RNA transcript, which was followed by a transient increase in the activity of the three enzymes. These results are consistent with the regulation of these genes and enzymes in other plant-elicitors interactions $(12,23)$ and indicate that (i) chitinase, $\beta$-1,3-glucanase, and PAL are regulated at the level of mRNA; and (ii) peach fruit are capable of responding to elicitor treatment analogously to other crops $(15,17,21)$. Although UV-C caused an increase of chitinase, $\beta$-1,3-glucanase, and PAL transcripts and activity in peach fruit, the level of mRNA induction of these enzymes is much lower than that reported of the same enzymes in vegetative tissue treated with various elicitors including UV-C $(4,7,13)$. This may be due to a differential regulation of these defense genes in harvested fruit. For instance, chitinase genes are regulated in a developmental and organ-specific pattern (16). Furthermore, in garlic leaves, chitinase concentration was 100 -fold higher than in bulbs (26). It also may be due to the induction of a fruit-specific gene or at least a different gene from the same family. This gene may have a different regulation and response than in other tissues. Lastly, we may be diluting out either the

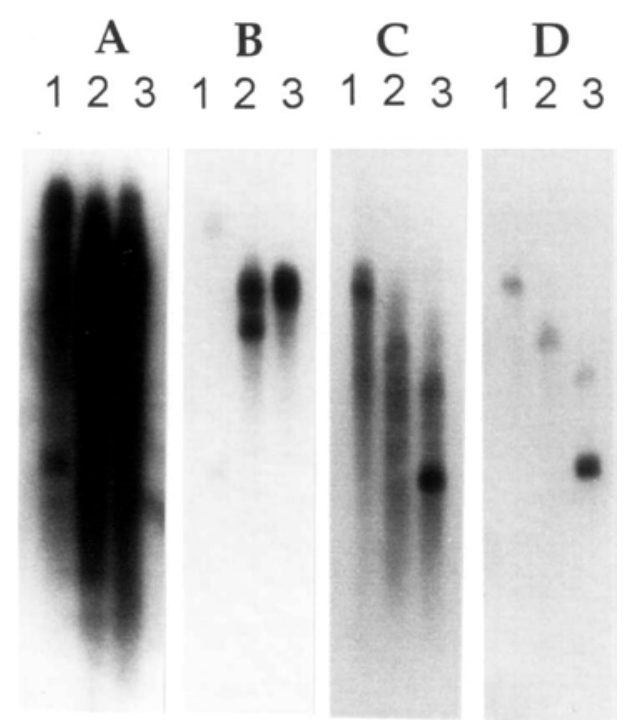

Fig. 4. DNA blot analyses of peach genomic DNA hybridized with peach chitinase and phenylalanine ammonia lyase (PAL) sequences. Lane $1=$ BamHI-digested DNA, lane $2=E c o$ RI-digested DNA, and lane $3=$ HindIIIdigested DNA. A, Probed with peach chitinase and washed at $2 \times \operatorname{SSC}(1 \times$ $\mathrm{SSC}$ is $0.15 \mathrm{M} \mathrm{NaCl}$ plus $0.015 \mathrm{M}$ sodium citrate) at $25^{\circ} \mathrm{C}$. B. Probed with peach chitinase and washed at $0.1 \times \mathrm{SSC}$ at $65^{\circ} \mathrm{C}$. C, Probed with peach PAL and washed at $2 \times \mathrm{SSC}$ at $25^{\circ} \mathrm{C}$. D, Probed with peach PAL and washed at $0.1 \times \mathrm{SSC}$ at $65^{\circ} \mathrm{C}$.
mRNA by the inclusion of mesocarp tissue while the induction is in the fruit pericarp or we may be filtering out the UV-C signal with the pericarp and its many UV-absorbing pigments.

Previously, we have shown that UV-C treatment of peach fruit induces resistance to brown rot caused by Monilinia fructicola and this was attributed to an induction of disease resistance by UV-C

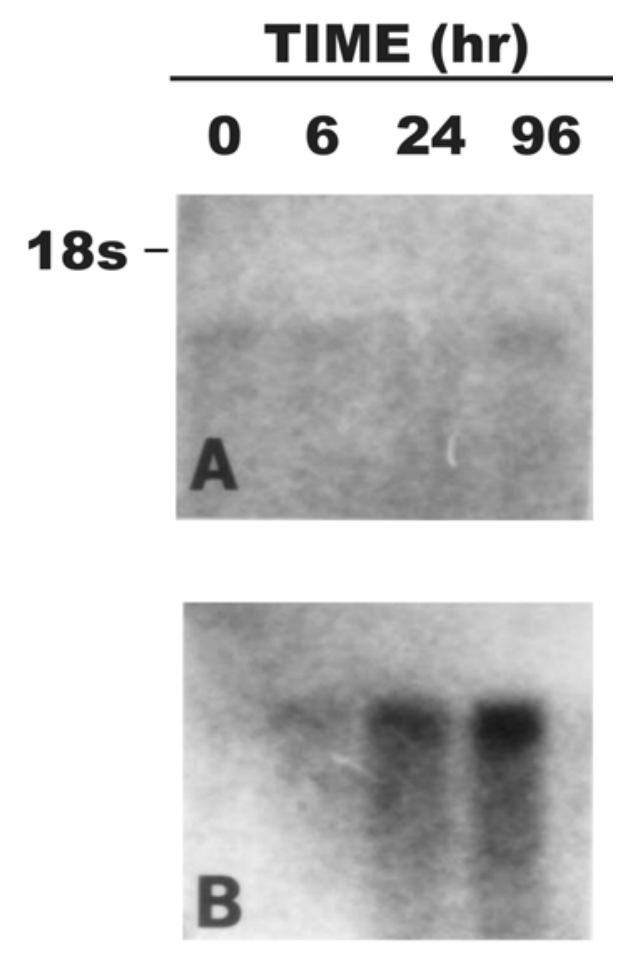

Fig. 5. RNA blot analysis of peach chitinase on peach fruit $\mathbf{A}$, untreated and B, treated with UV-C. Time represents the number of hours after treatment when the fruit was sampled. $18 \mathrm{~S}$ indicates where the lower ribosomal fragment runs on the stained gel. There is an increase of chitinase transcript in response to UV-C treatment.

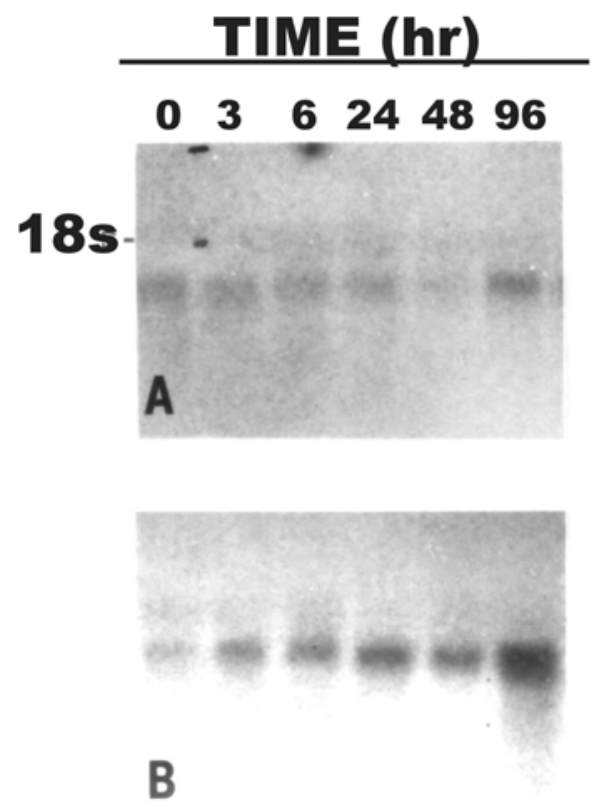

Fig. 6. RNA blot analysis of $\beta$-1,3-glucanase on peach fruit $\mathbf{A}$, untreated and B, treated with UV-C. Time represents the number of hours after treatment when the fruit was sampled. 18S indicates where the lower ribosomal fragment runs on the stained gel. There is an increase of $\beta-1,3$-glucanase transcript in response to UV-C treatment. 
treatment (24). Although a causal relationship remains to be determined, the observed increase in chitinase, $\beta$-1,3-glucanase, and PAL activity by UV-C treatment suggests a putative involvement of these enzymes in UV-C-mediated disease resistance. This is further supported by the fact that the timing of the induced accumulation of chitinase, $\beta$-1,3-glucanase, and PAL activities coincides with the onset of disease resistance in UV-C-treated peach fruit, which occurred within 24 to $48 \mathrm{~h}$ after UV-C treatment. Chitinase and $\beta$-1,3-glucanase, either alone or in combination, are antifungal in vitro (22), and in several plant systems, their expression is often correlated with the onset of the elicitor-mediated resistance $(15,17,21,25)$. PAL is a key intermediate in the shikimic acid pathway that leads to the synthesis of phenols, phytoalexins, and lignin that are all associated with the localized resistance processes (21).

In conclusion, these results show that the treatment of peach fruit with UV-C light induced the accumulation of chitinase, $\beta$ 1,3-glucanase, and PAL transcripts, which was followed by a transient increase in the activity of these three enzymes. This demonstrates that regulation of defense responses in peach fruit in response to elicitor treatment is similar to that in other plant systems. Furthermore, our results suggest that the expression of peach defense genes and enzymes is at least partially responsible for previously reported UV-C-mediated resistance in peach fruit and, more importantly, show that the concept of induced resistance could be manipulated in harvested commodities.
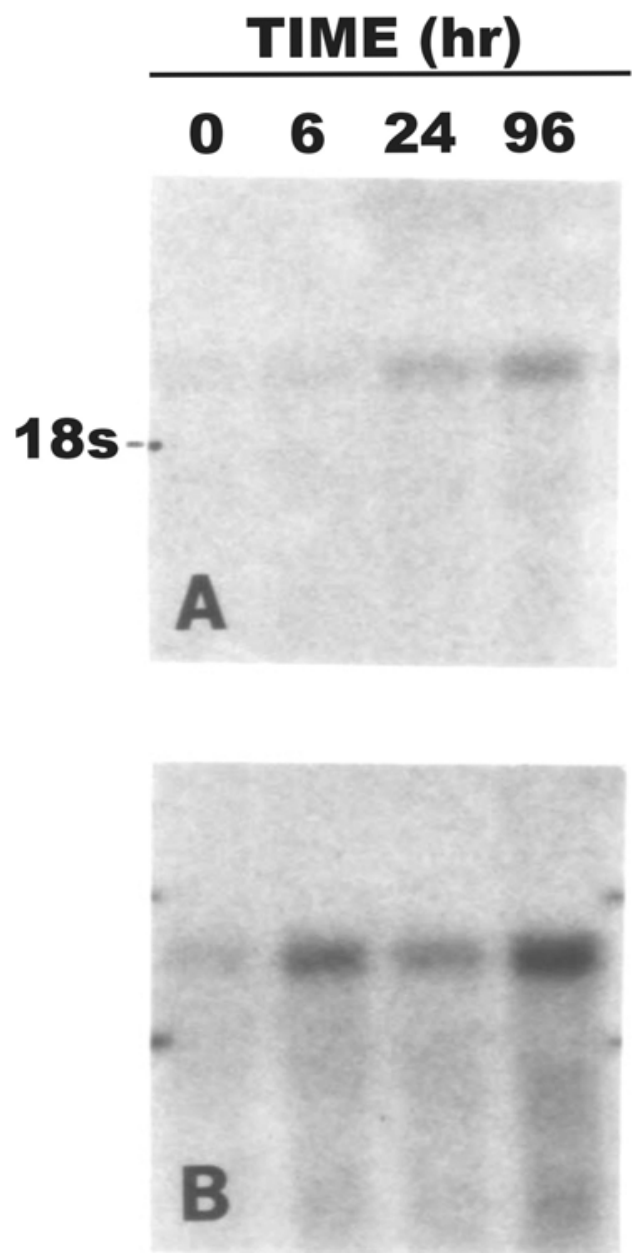

Fig. 7. RNA blot analysis of peach phenylalanine ammonia lyase (PAL) on peach fruit $\mathbf{A}$, untreated and $\mathbf{B}$, treated with UV-C. Time represents the number of hours after treatment when the fruit was sampled. 18S indicates where the lower ribosomal fragment runs on the stained gel. There is an increase of peach PAL transcript in response to UV-C treatment.

\section{LITERATURE CITED}

1. Abeles, F. B., and Forrence, L. E. 1970. Temporal and hormonal control $\beta$-1,3-glucanase in Phaseolus vulgaris L. Plant Physiol. 45:395-400.

2. Amaravadi, L., and King, M. W. 1994. A rapid and efficient, non-radioactive method for screening recombinant DNA libraries. Biotechniques 16:99-104

3. Beaudoin-Eagan, L. D., and Thorpe, T. A. 1985. Tyrosine and phenylalanine ammonia lyase activities during shoot initiation in tobacco callus cultures. Plant Physiol. 78:438-441.

4. Brederode, T. F., Linthorst, J. M. H., and Bol, F. J. 1991. Differential induction of acquired resistance and PR gene expression in tobacco by virus infection, ethephon treatment, UV light and wounding. Plant Mol. Biol. 17:1117-1125.

5. Callahan, A., Morgens, P., and Walton, E. 1989. Isolation and in vitro translation of RNAs from developing peach fruit (Prunus persica $\mathrm{L}$. Batsh Reliance). HortScience 24:356-358.

6. Chalutz, E., Droby, S., Wilson, C., and Wisniewski, M. 1992. UV-induced resistance to postharvest diseases of citrus fruit. J. Phytochem. Phytobiol. 15:367-374.

7. Christ, U., and Mosinger, E. 1989. Pathogenesis-related proteins of tomato: I. Induction by Phytophthora infestans and other biotic and abiotic inducers and correlation with resistance. Physiol. Mol. Plant Pathol. 35:137-147.

8. Doyle, J. J., and Doyle, J. L. 1990. Isolation of plant DNA from fresh tissue. Focus 12:13-15.

9. Eckenrode, V. K., and Arnold, J., and Meagher, R. B. 1985. Comparison of the nucleotide sequence of soybean $18 \mathrm{~S}$ rRNA with the sequences of other small-subunit rRNAs. J. Mol. Evol. 21:259-269.

10. El Ghaouth, A., Arul, J., and Asselin, A. 1992. Potential use of chitosan in postharvest preservation of fruits and vegetables. Pages 440452 in: Advances in Chitin and Chitosan. J. B. Brines, P. A. Sandford, and J. P. Zikakis, eds. Elsevier Applied Science, Amsterdam, the Netherlands.

11. Friedrich, L., Lawton, K., Ruess, W., Masner, P., Specker, N., Gut Rella, M., Meier, B., Dincher, S., Staub, S., and Uknes, S. 1996. A benzothiadiazole derivative induces systemic acquired resistance in tobacco. Plant J. 10:61-70.

12. Habereder, H., Schroder, D., and Ebel, J. 1989. Rapid induction of phenylalanine ammonia lyase and chalcone synthase mRNAs during fungus infection of soybean (Glycine $\max \mathrm{L}$.) roots or elicitor treatment of soybean cell cultures at the onset of phytoalexin synthesis. Planta 177:58-65.

13. Hadwiger, L. A., and Schwochau, M. E. 1971. Ultraviolet light-induced formation of pisatin and phenylalanine ammonia lyase. Plant Physiol. 47:588-590.

14. Herrin, D. L., and Schmidt, F. W. 1988. Rapid reversible staining of northern blots prior to hybridization. Biotechniques 6:196-200.

15. Kessmann, H., Oostendorp, M., Ruess, W., Staub, T., Kunz, W., and Ryals, J. 1996. Systemic activated resistance-A new technology for plant disease control. Pestic. Outlook 7:10-13.

16. Kombrinck, E., and Somssich, I. E. 1995. Defense responses of plant to pathogens. Adv. Bot. Res. 21:1-34.

17. Kuc, J., and Strobel, N. 1992. Induced resistance using pathogens and nonpathogens. Pages 295-303 in: Biological Control of Plant Diseases. E. Tjamos, G. Papavisas, and R. J. Cook, eds. Plenum Press, New York.

18. Lers, A., Burd, S., Lomnaniec, E., Droby, S., and Chalutz, E. 1998. The expression of grapefruit gene encoding an isoflavone reductase-like protein is induced in response to UV irradiation. Plant Mol. Biol. 36:847-856.

19. Mercier, J., Arul, J., Ponnampalam, R., and Boulet, M. 1993. Induction of 6-methoxymellein and resistance to storage pathogens in carrot slices by UV-C. J. Phytopathol. 137:44-55.

20. Rodov, V., Ben-Yehoshua, S., Albaglis, R., and Fang, D. 1994. Accumulation of phytoalexins scoparone and scopoletin in citrus fruits subjected to various postharvest treatments. Acta Hortic. 381:517523.

21. Ryalls, J., Neuenschwander, U., Willits, M., Molina, A., Steiner, H. Y., and Hunt, M. 1996. Systemic acquired resistance. Plant Cell 8:18091819.

22. Schlumbaum, A., Mauch, F., Vogeli, U., and Boller, T. 1986. Plant chitinases are potent inhibitors of fungal growth. Nature 324:365-367.

23. Schroder, M., Hahlbrock, K., and Kombrink, E. 1992. Temporal and spatial patterns of $\beta$-1,3-glucanase and chitinase induction in potato leaves infected by Phytophthora infestans. Plant J. 2:161-172.

24. Stevens, C., Khan, V. A., Lu, J. Y., Wilson, C. L., Pusey, P. L., Kabwe, M. K., Igwegbe, E. C. K., Chalutz, E., and Droby, S. 1998. The 
germicidal and hormetic effects of UV-C light on reducing brown rot disease and yeast microflora of peaches. Crop Prot. 17:75-84.

25. Sticher, L., Mauch-Mani, B., and Metraux, J. P. 1997. Systemic acquired resistance. Annu. Rev. Phytopathol. 35:235-270.

26. Van Damme, E. J. M., Willems, P., Torrekens, S., Van Leuven, F., and
Peumans, W. J. 1993. Garlic (Allium sativum) chitinases: Characterization and molecular cloning. Physiol. Plant 87:177-186.

27. Wirth, S. A., and Wolf, G. A. 1990. Dye-labelled substrates for the assay and detection of chitinase and lysozyme activity. J. Microbiol. Methods 11:197-205. 